\title{
Growth and nutrient removal properties of the diatoms, Chaetoceros curvisetus and $C$. simplex under different nitrogen sources
}

\author{
Panneerselvam Karthikeyan • Kuppusamy Manimaran • \\ Pitchai Sampathkumar · Lakshmanan Rameshkumar
}

Received: 2 June 2011/Accepted: 20 August 2012/Published online: 6 September 2012

(C) The Author(s) 2012. This article is published with open access at Springerlink.com

\begin{abstract}
To investigate the suitability of the marine diatoms, Chaetoceros curvisetus and C. simplex for the removal of macronutrients from different wastewater, the growth and nitrate-phosphate removal properties were studied with nitrate, ammonium and urea nitrogen sources. Three separate experiments were conducted using modified F/2 medium with $12.35 \mathrm{mg} \mathrm{L}^{-1}$ total nitrogen and $1.12 \mathrm{mg} \mathrm{L}^{-1}$ total phosphorous (simulating the typical concentration of nitrogen and phosphorus in secondary effluent) as growth medium. The maximum cell densities of $C$. curvisetus and $C$. simplex were $7.16 \pm 0.34 \times 10^{4}$ cells $\mathrm{mL}^{-1}$ in $\mathrm{NO}_{3}^{-}$and $3.88 \pm 0.32 \times$ $10^{5}$ cells $\mathrm{mL}^{-1}$ in urea, respectively. The maximum chlorophyll $a$ per cell was 1.7 and $4.7 \mathrm{pg}$ for $C$. simplex and C. curvisetus, cultured with urea and nitrate, respectively. The high protein contents of $4.7 \mathrm{pg}$ cell $^{-1}$ in $C$. simplex with urea and $19.7 \mathrm{pg} \mathrm{cell}^{-1}$ in $C$. curvisetus nitrate nitrogen sources were found. The higher cell density and protein content of both species from urea and nitrate nitrogen sources $(p<0.05)$ have shown that these were utilized by microalgae and were converted to protein. The $C$. simplex and $C$. curvisetus showed maximum removal efficiencies of nitrate by 97.86 and $91.62 \%$ and phosphate by 98.5 and $100 \%$, respectively when urea used as nitrogen source than ammonia. The results indicated the $C$. simplex was more efficient than $C$. curvisetus and suitable for the removal of macronutrients when cultured with urea and nitrate nitrogen sources.
\end{abstract}

\footnotetext{
P. Karthikeyan · K. Manimaran · P. Sampathkumar $(\bowtie)$.

L. Rameshkumar

Centre of Advanced Study in Marine Biology, Faculty of Marine

Sciences, Annamalai University, Parangipettai 608 502,

Tamil Nadu, India

e-mail: sampathcas@gmail.com

P. Karthikeyan

e-mail: vetrikarthy@gmail.com
}

Keywords Growth · Wastewater treatment . Phytoplankton · Nitrogen sources .

Biochemical composition

\section{Introduction}

The input of nutrients especially nitrogen and phosphorus by human activities increased into biochemical cycles through agricultural practices, urbanization, industrialization and other activities. The widespread use of nitrogen fertilizers, following discharges of agricultural and industrial effluents resulted in the pollution of aquatic environment and is the main cause of eutrophication (Karthikeyan et al. 2010; Manimaran et al. 2011). Nutrient enrichment or eutrophication of aquatic ecosystems can cause an increase in algae and aquatic plants, loss of component species and loss of ecosystem function. In connection with these problems, numerous studies have aimed on nitrogen and phosphorus removal from wastewater (Thakur and Kumar 1999). Most of these studies are based on biological processes and different combinations of anaerobic, aerobic and anoxic zones (Aslan and Kapdan 2006). It was reported that nitrate and phosphate could be effectively taken up by photosynthetic microorganisms namely, cyanobacteria and green algae. The phytoplankton has many advantages for application to nitrate and phosphate removal than macrophytes. It proliferates throughout the entire year with high growth rates when environmental conditions such as light, nutrients and water temperature are suitable (Alexander and Goldman 1994). Free-living and immobilized cells of microalgae have been extensively studied and used for the removal of the inorganic compounds from water (Garbisu et al. 1992; Urrutia et al. 1995; Gonzalez-Bashan et al. 2000; Tam and Wong 2000).

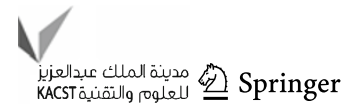


The advantages of using algae includes the low cost of the operation, the possibility of recycling assimilated nitrogen and phosphorus into algae biomass as a fertilizer, avoiding a sludge handling problem and the discharge of oxygenated effluent into the water body (Hu et al. 2000). In addition, the process has no carbon requirement for nitrogen and phosphorus removal, which is attractive for the treatment of secondary effluents (Aslan and Kapdan 2006). The concentrations of nitrate, phosphate in different sources (urea, nitrate and ammonia) in the secondary effluents vary depending on the wastewater characteristics (Aslan and Kapdan 2006). The total nitrogen concentration was reported as $788 \mathrm{mg} \mathrm{L}^{-1}$ in pretreated piggery wastewater by An et al. (2003) and around $1,450 \mathrm{mg} \mathrm{L}^{-1}$ by Olguin et al. (2003). The average values of $\mathrm{NH}_{4}^{+}$and $\mathrm{PO}_{4}^{-}$were $27.4 \mathrm{mg} \mathrm{L}^{-1}$ and $11.8 \mathrm{mg} \mathrm{L}^{-1}$, respectively in the conventional secondary treatment effluent of domestic wastewater (Martinez et al. 2000) whereas they were $48 \mathrm{mg} \mathrm{NH}_{4}^{+}$ $\mathrm{L}^{-1}$ and $16 \mathrm{mg} \mathrm{PO}_{4}^{-} \mathrm{L}^{-1}$ in the effluent of up-flow sludge blanket reactor, fed with domestic sewage (Van der Steen et al. 1999). The wastewater treatment with microalgae was reported in the use of high-rate algae ponds (HRAP) (Cromar et al. 1996; Deviller et al. 2004). Recently corrugated raceways (Olguin et al. 2003), a triangular photobioreactor (Dumas et al. 1998) and a tubular photobioreactor (Cattaneo et al. 2003) have been developed for nutrient removal. The microalgae Chlorella sp., Scenedesmus sp., Spirulina sp., Nannochloropsis sp. and Phormidium sp. have been widely investigated and used for nutrient removal from wastewater (Lee and Lee 2001; Gonzales et al. 1997; Martinez et al. 1999; 2000; Olguin et al. 2003; JimenezPerez et al. 2004; Laliberte et al. 1997; Dumas et al. 1998).

Many studies have focused on the objective of optimization of nitrogen and phosphorous removal and environmental factors influencing on microalgal growth, such as nutrient concentration (Aslan and Kapdan 2006), nutrient type (Hyenstrand et al. 2000), light availability (Janssen et al. 2000) and $\mathrm{pH}$ (Xin et al. 2010). Wastewater may contain different forms of nitrogen (nitrate, ammonium, urea, etc.), so it is important to know the effect of different nitrogen compounds on microalgal growth and nutrient removal (Xin et al. 2010). Among the phytoplankton, diatoms are contributing higher diversity and biomass production in marine environment and not well recognized for bioremediation purposes. The centric diatoms, $C$. curvisetus and $C$. simplex were studied extensively for their biochemical composition and used for larval diet in aquaculture practices. But the reports are very limited in the use of diatoms for wastewater treatment. Hence the present investigation focused on the objective of growth, biochemical composition and NP removal properties of these two marine diatoms with three different nitrogen sources viz. nitrate, urea and ammonia.

\section{Materials and methods}

\section{Microalgae}

The marine centric diatoms, $C$. curvisetus and $C$. simplex were isolated by serial dilutions in F/2 media from Vellar estuary, Southeast coast of India. The stock cultures were maintained in Guillard F/2 media following the methods described in Andersen (2005).

\section{Experimental setup}

The modified F/2 medium with $12.35 \mathrm{mg} \mathrm{L}^{-1} \mathrm{TN}$ and $1.12 \mathrm{mg} \mathrm{L}^{-1} \mathrm{TP}$ (simulating the typical concentration of nitrogen and phosphorus in secondary effluent) was used as growth medium. In all experiments, $\mathrm{K}_{2} \mathrm{HPO}_{4} \cdot 3 \mathrm{H}_{2} \mathrm{O}$ (5.6 $\mathrm{mg} \mathrm{L}^{-1}$ ) was used as phosphorus source. Besides nitrogen and phosphorus, the composition of other elements was the same with $F / 2$ medium.

All the experiments were conducted in 5,000-ml Erlenmeyer flasks with 3,000-ml algal cultures in three replicates. The subcultures of $C$. simplex and $C$. curvisetus were maintained with three kinds of nitrogen sources, $\mathrm{NaNO}_{3}\left(75 \mathrm{mg} \mathrm{L}^{-1}\right.$ and $24.72 \mathrm{mg} \mathrm{L}^{-1}$ of $\mathrm{NaNO}_{3}$ and $\mathrm{TN}$, respectively), $\mathrm{NH}_{4} \mathrm{Cl}$ (47 $\mathrm{mg} \mathrm{L}^{-1}$ and $24.72 \mathrm{mg} \mathrm{L}^{-1}$ of $\mathrm{NH}_{4} \mathrm{Cl}$ and $\mathrm{TN}$, respectively) and urea $\left(53 \mathrm{mg} \mathrm{L}^{-1}\right.$ and $22.35 \mathrm{mg} \mathrm{L}^{-1}$ of urea and $\mathrm{TN}$, respectively) for 7 days. The cell density was estimated at every $24 \mathrm{~h}$ intervals; the total nitrogen and phosphorous were analysed in culture medium, before inoculation of algal cells and after 7 days of culture. The protein and carbohydrate contents were estimated at the end of the experiment.

\section{Growth rate}

The growth rate was calculated using the following formula (OECD 2002),

$\mu=N_{x}-N_{0} / t_{x}-t_{0}$

Where $N_{O}$ is the number of cells in time zero, $N_{x}$ is the number of cells in time $x, t_{0}$ is the starting time $(0)$ and $t_{x}$ is the time $x$ (in days).

\section{Doubling time}

The doubling time was calculated by the following formula (Karthikeyan et al. 2011),

Doubling time $=\left(N_{0} \times 2\right) /\left(N_{t}\right) \times t$

where, $N_{O}$ is the number of cells in time zero, $N_{t}$ is the number of cell in time $t, t$ is the time in hours. The results were presented in doubling time (DT) in hours. 
Parameters maintained

During isolation, stock culture maintenance and experiments were conducted; the parameters viz. temperature, light intensity, photoperiod and salinity were maintained as $24 \pm 2{ }^{\circ} \mathrm{C}, 4500 \pm 500$ Lux, $14 \pm 1: 8 \pm 1$ h (light:dark) and $30 \mathrm{psu}$, respectively.

\section{Analytical methods}

The total nitrogen and total phosphate were estimated at the beginning and the end of the experiment in cell-free media by centrifugation followed by Strickland and Parsons (1972). After 7 days of culture, the cells were isolated by centrifugation and the pellet used for further analysis of protein and carbohydrate. The protein was estimated by Folin's phenol reagent method (Lowry et al. 1951) and the carbohydrate was estimated by phenol sulphuric acid method (Dubois et al. 1956).

\section{Data analysis}

Three replicates of each sample were used for statistical analysis and the values were reported as mean $\pm \mathrm{SD}$. Oneway ANOVA and Duncan's multi-variant analysis were carried out using SPSS, version 16.0 software to study the difference between nitrogen sources and species.

\section{Results}

The growth curves of $C$. curvisetus and $C$. simplex with different nitrogen sources are shown in Fig 1. The C. curvisetus was grown fastest in $\mathrm{NO}_{3}^{-}$followed by urea whereas C. simplex was grown fastest in urea followed by $\mathrm{NO}_{3}^{-}$. The organisms grew slowest on ammonia. The maximum cell density of $7.16 \pm 0.34 \times 10^{4}$ cells $\mathrm{mL}^{-1}$ (growth rate $1.16 \mu$ day $^{-1}$ ) and $3.88 \pm 0.32 \times 10^{5}$ cells $\mathrm{mL}^{-1}$ (growth rate $0.59 \mu \mathrm{day}^{-1}$ ) of $C$. curvisetus and $C$. simplex were found in $\mathrm{NO}_{3}^{-}$and urea, respectively (Fig. 1 and Table 2). The maximum chlorophyll $a$ per cell was 1.7 and $4.7 \mathrm{pg}$ for C. simplex and C. curvisetus which were cultured with urea and nitrate, respectively. The Chl $a$ of $3.9 \mathrm{pg} \mathrm{cell}^{-1}$ was observed in urea used as nitrogen source in the medium for C. curvisetus and $1.6 \mathrm{pg} \mathrm{cell}^{-1}$ for $C$. simplex in nitrate (Fig 5). The protein content of $C$. simplex did not showed any significant variations with urea and nitrate nitrogen sources (4.7 $\mathrm{pg} \mathrm{cell}^{-1}$ in urea and $4.6 \mathrm{pg} \mathrm{cell}^{-1}$ in $\mathrm{NO}_{3}^{-}$) where it was $3.4 \mathrm{pg} \mathrm{cell}^{-1}$ in ammonia nitrogen. The maximum protein of 19.7 and $16.8 \mathrm{pg} \mathrm{cell}^{-1}$ was found in C. curvisetus cultured with nitrate and urea, respectively. The carbohydrate contents of $C$. simplex were $0.86,0.78$ and $0.62 \mathrm{pg} \mathrm{cell}^{-1}$, whereas it was $3.6,4.5$ and $0.4 \mathrm{pg} \mathrm{cell}^{-1}$ in

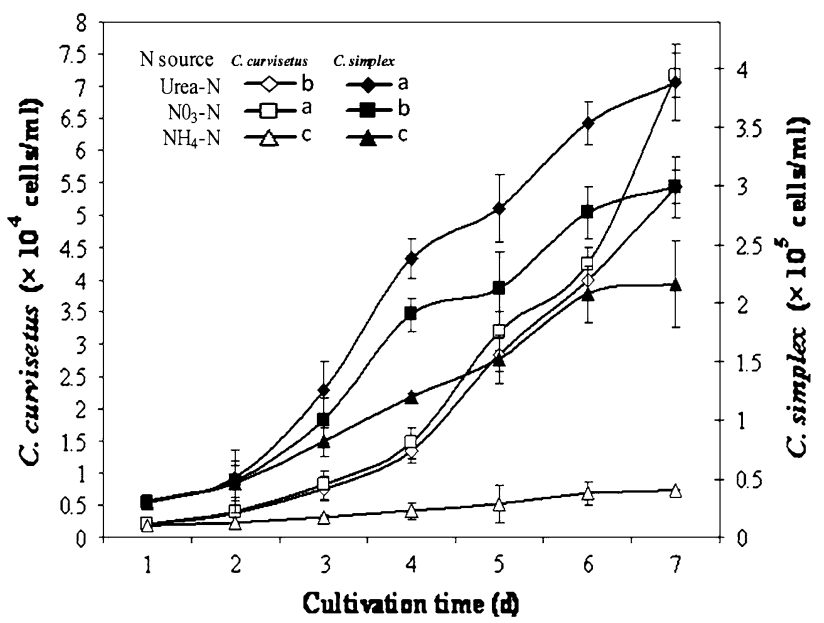

Fig. 1 Growth of $C$. curvisetus and $C$. simplex under three different nitrogen sources. Each value represents mean $\pm \mathrm{SD}(n=3)$. Each species with different alphabet letters are significantly different $(p \leq 0.05)$

C. curvisetus with urea, nitrate and ammonia nitrogen, respectively (Fig. 6). The order of specific growth rate, chlorophyll, protein and carbohydrate contents with different nitrogen sources were $\mathrm{NH}_{4}^{+}<$urea $<\mathrm{NO}_{3}^{-}$of $C$. curvisetus and $\mathrm{NH}_{4}^{+}<\mathrm{NO}_{3}^{-}<$urea of $C$. simplex, respectively (Table 1; Figs. 2, 3, 4).

The capacity of nitrate and phosphate removal differed between the species as well as among the nitrogen sources used (Fig. 4). The observations in the present study showed that both species performed well in the removal of both $\mathrm{N}$ and $\mathrm{P}$ when urea used as nitrogen source in culture medium. Next to urea, the nitrate was observed as a good source of nitrogen for each species in the removal of $\mathrm{N}$ and $\mathrm{P}$. The removal of nitrate was 97.86 and $91.62 \%$; the phosphate was 98.5 and complete removal by $C$. simplex and $C$. curvisetus, respectively cultured with urea source for 7 days (Fig. 3). When compared to urea and nitrate the slow growth of the both species was observed with ammonia (Fig. 1). The order of nitrate and phosphate removal capacities with different nitrogen sources was $\mathrm{NH}_{4}^{+}<\mathrm{NO}_{3}^{-}<$urea of C. curvisetus and $\mathrm{NH}_{4}^{+}<$urea $<\mathrm{NO}_{3}^{-}$of $C$. simplex respectively (Table 1 ). The one-way ANOVA results that showed the nitrogen sources and the two species were significantly different for their growth, nitrate phosphate removal and biochemical compositions.

\section{Discussion}

The microalgae could be used for the removal of phosphate and nitrate from wastewater. In this present study, the order of specific growth rate, chlorophyll, protein and carbohydrate contents with different nitrogen sources was $\mathrm{NH}_{4}^{+}<$urea $<\mathrm{NO}_{3}^{-}$of 
Fig. 2 Nitrogen removal properties of $C$. simplex and C. curvisetus under three different nitrogen sources. Each value represents mean $\pm \mathrm{SD}$ $(n=3)$

Fig. 3 Phosphate removal properties of $C$. simplex and C. curvisetus under three different nitrogen sources

Fig. 4 Variations of Nitrate Phosphate removal of C. simplex and C. curvisetus under three different nitrogen sources. Each nitrogen sources (bars) with different alphabet letters of species are significantly different $(p \leq 0.05)$
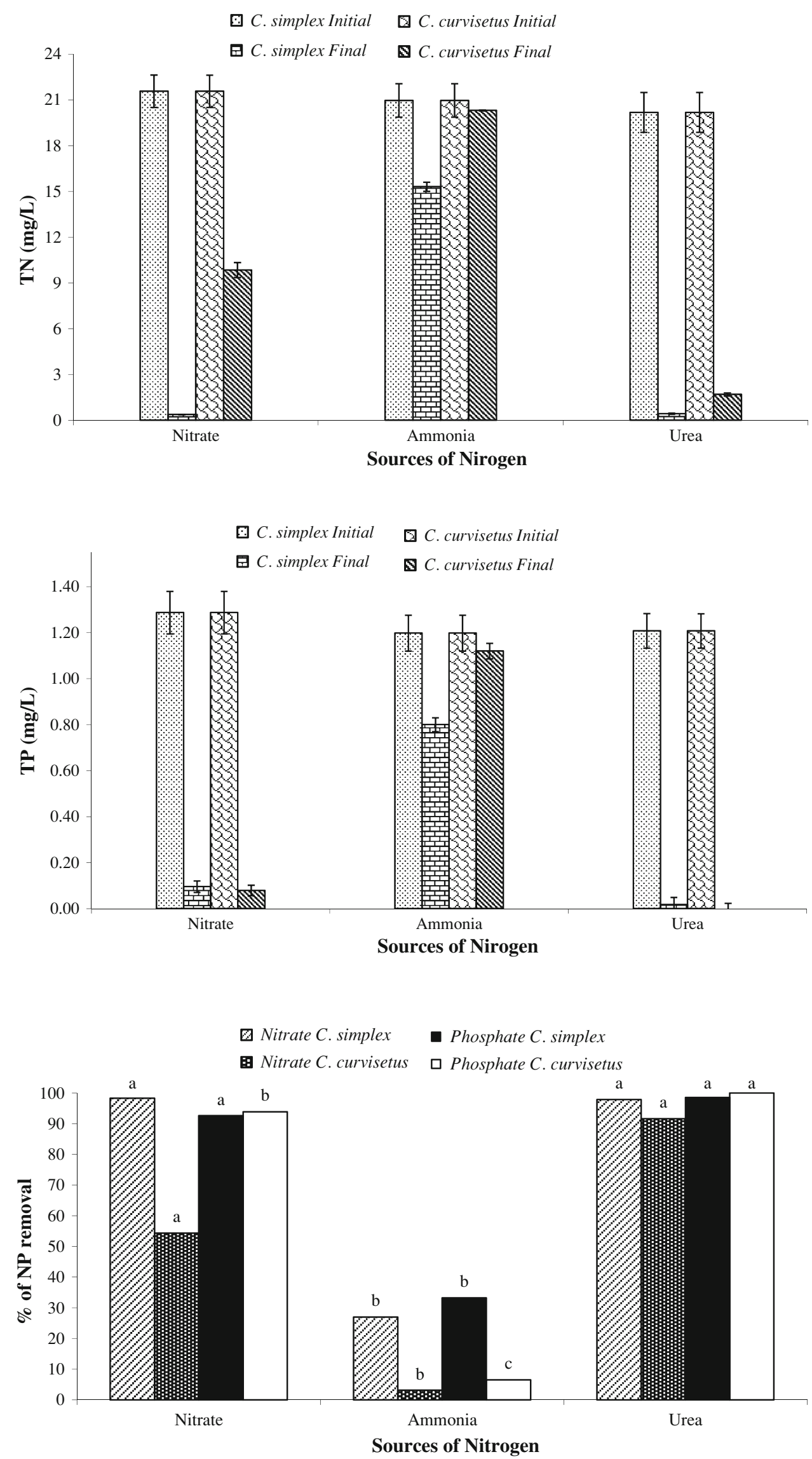


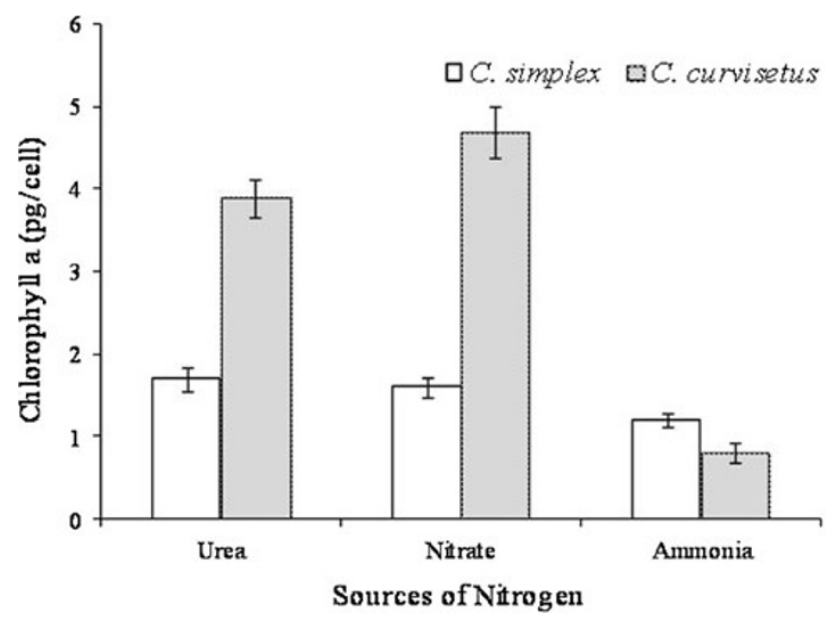

Fig. 5 Chlorophyll $a$ concentration of $C$. simplex and C. curvisetus under three different nitrogen sources
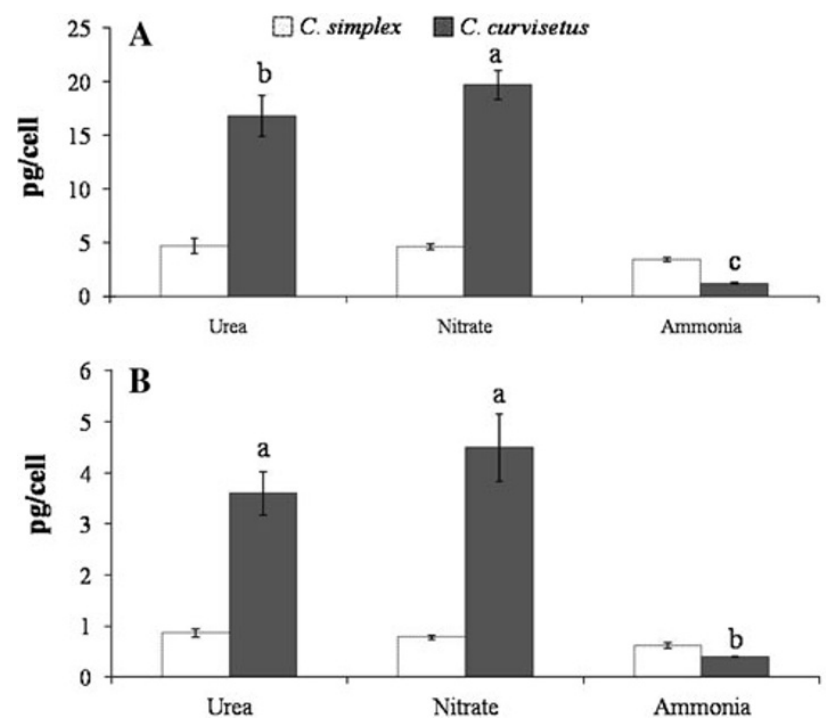

Fig. 6 Protein (a) and carbohydrate (b) contents of $C$. simplex and $C$. curvisetus under different nitrogen sources. Each nitrogen sources (bars) with different alphabet letters are significantly different $(p \leq 0.05)$

Table 1 The order of specific growth rate, N:P removal efficiency, protein and carbohydrate contents of the diatom with different nitrogen sources

\begin{tabular}{lll}
\hline & C. curvisetus & C. simplex \\
\hline Growth rate & $\mathrm{NH}_{4}^{+}<$urea $<\mathrm{NO}_{3}^{-}$ & $\mathrm{NH}_{4}^{+}<\mathrm{NO}_{3}^{-}<$urea \\
Chlorophyll & $\mathrm{NH}_{4}^{+}<$urea $<\mathrm{NO}_{3}^{-}$ & $\mathrm{NH}_{4}^{+}<\mathrm{NO}_{3}^{-}<$urea \\
Nitrate removal & $\mathrm{NH}_{4}^{+}<\mathrm{NO}_{3}^{-}<$urea & $\mathrm{NH}_{4}^{+}<$urea $<\mathrm{NO}_{3}^{-}$ \\
Protein content & $\mathrm{NH}_{4}^{+}<$urea $<\mathrm{NO}_{3}^{-}$ & $\mathrm{NH}_{4}^{+}<\mathrm{NO}_{3}^{-}<$urea \\
Carbohydrate content & $\mathrm{NH}_{4}^{+}<$urea $<\mathrm{NO}_{3}^{-}$ & $\mathrm{NH}_{4}^{+}<\mathrm{NO}_{3}^{-}<$urea \\
\hline
\end{tabular}

C. curvisetus and $\mathrm{NH}_{4}^{+}<\mathrm{NO}_{3}^{-}<$urea of $C$. simplex, respectively (Table 1). The order of growth rate and nutrient removal of C. curvisetus was similar to Scenedesmus sp. LX1 after 13 days
Table 2 Growth rate of $C$. curvisetus and $C$. simplex with different nitrogen sources

\begin{tabular}{lll}
\hline & C. curvisetus & C. simplex \\
\hline Urea-N & $0.87 \pm 0.037^{\mathrm{b}}$ & $0.59 \pm 0.012^{\mathrm{a}}$ \\
$\mathrm{NO}_{3}^{-}-\mathrm{N}$ & $1.16 \pm 0.045^{\mathrm{a}}$ & $0.45 \pm 0.013^{\mathrm{b}}$ \\
$\mathrm{NH}_{4}^{+}-\mathrm{N}$ & $0.09 \pm 0.011^{\mathrm{c}}$ & $0.31 \pm 0.01^{\mathrm{c}}$ \\
\hline
\end{tabular}

Different superscripts in column are significantly different $(p \leq 0.05)$

of cultivation with nitrate, ammonium and urea as nitrogen sources (Xin et al. 2010). But the C. simplex was grown fastest with urea and the higher growth rate was observed in the present study from urea nitrogen (Fig. 2). When urea used as a nitrogen source, the initial $\mathrm{pH}$ of the medium is slightly high compared to other nitrogen sources. This might be the reason for highest growth rate of $C$. simplex in urea (Garcia et al. 2006; Xin et al. 2010). Other than this reason, the $C$. simplex is very smaller in cell size and bio-volume than $C$. curvisetus. So the growth rate and doubling time of $C$. simplex were higher than C. curvisetus in this present study. The algal growth in the present study with ammonium nitrogen was significantly low. However, the ammonium is good nitrogen source for the phytoplankton growth, the unfavorable concentration causes growth inhibition due to toxicity and/or acidifying the culture media during algal growth (Garcia et al. 2006; Xin et al. 2010).

After 7 days of cultivation with nitrate, ammonium and urea as nitrogen sources, TN removal efficiencies of $C$. simplex was significantly high with urea and nitrate nitrogen. But, C. curvisetus efficiently removed the TN from the media in the presence of nitrate nitrogen. The TP removal capacities were also observed in the same trend as TN removal. The TN and TP removal capacities of the diatoms in this study were slightly lower than Scenedesmus sp. LX1 after 13 days cultivation (Xin et al. 2010). However, the nutrient removal efficiencies of these two diatoms were higher than Chlorella spp. and Phormidium bohneri (Dumas et al. 1998; Lee and Lee 2001; Valderrama et al. 2002). The growth and nutrient uptake properties of these two species significantly varied because each species require unique suitable environmental conditions such as light intensity, temperature and salinity, etc. (Aslan and Kapdan 2006). From the available literatures, the different kinds of biomolecules have been produced in a single species of microalgae with changing environmental parameters.

Aslan and Kapdan (2006) found that the $\mathrm{NH}_{4}^{+}$was completely removed from the media by Chlorella vulgaris when the initial concentration was between 13.2 and $21.2 \mathrm{mg} \mathrm{L}^{-1}$. Further, the removal efficiency of $\mathrm{NH}_{4}^{+}$was decreased to less than $24 \%$ when the $\mathrm{NH}_{4}^{+}$concentration was higher than $129 \mathrm{mg} \mathrm{L}^{-1}$. In the present study, the initial $\mathrm{NH}_{4}^{+}$concentration was $47 \mathrm{mg} \mathrm{L}^{-1}$ and the nitrate removal was 26.9 and $3.1 \%$ by C. simplex and C. curvisetus, respectively. 
The chlorophyll content of $C$. simplex and $C$. curvisetus estimated in this study was slightly varied with cell density and nitrogen sources. The nutrient concentrations also influenced the chlorophyll $a$ concentration and light intensity with major significance (Sciandra et al. 2000; Young and Beardall 2003; Lafarga-De la Cruz et al. 2006; Eker-Develi et al. 2006).

The protein and carbohydrate contents of $C$. simplex and C. curvisetus in this present study are under the range of reported amounts in other diatoms like Chaetoceros calcitrans, C. gracilis, Nitzchia closterium, Phaeodactylum tricornutum, Skeletonema costatum, Thalassiosira pseudonana and Tetraselmis chui by Brown (1991). So, the biomass produced after wastewater treatment could be used for many purposes after required precautions such as sterilization, etc.

\section{Conclusions}

Further optimization of other environmental parameters can improve the nutrient removal efficiency of $C$. curvisetus. If ammonium was the main nitrogen source in wastewater, a buffer solution should be added to keep $\mathrm{pH}$ above 7.5 for algal growth and nutrient removal.

Acknowledgments We are thankful to Dr. T. Balasubramanian, Dean, CAS in Marine Biology, Faculty of Marine Sciences, Annamalai University, Parangipettai and MoES-ICMAM to carry out the present work for providing facilities and fellowship to Mr. P. Karthikeyan, Mr. K. Manimaran.

Open Access This article is distributed under the terms of the Creative Commons Attribution License which permits any use, distribution, and reproduction in any medium, provided the original author(s) and the source are credited.

\section{References}

Alexander JH, Goldman CR (1994) Limnology, 2nd edn. McgrawHill, New York, pp 193-263

An JY, Sim SJ, Lee JS, Kim BK (2003) Hydrocarbon production from secondary treated piggery wastewater by the green algae. Botrycoccus braunii. J Appl Phycol 15:185-191

Andersen RA (2005) Algal culturing techniques. Elsevier Academic Press, Burlington. ISBN 0-12-088426-7

Aslan S, Kapdan IK (2006) Batch kinetics of nitrogen and phosphorus removal from synthetic wastewater by algae 'Dokuz eylu' University, Department of Environmental Sebnem Engineering, Kaynaklar Campus, 35160 Buca-IZMIR. Turk ecol eng 28:64-70

Brown MR (1991) The amino acid and sugar composition of 16 species of microalgae used in mariculture. Aquacult 145:79-99

Cattaneo C, Zolezzi M, Rovatti P, Fabiano M, Povero P, Rovatti M (2003) Growth and nutrient uptake of microalgae (Nannochloropsis sp.) in a tubular photo bioreactor. In: Pierucci S (ed) IcheaP-6 the six italian conference on chemical and process engineering florance, vol 1, pp 1677-1682
Cromar NJH, Fallowfield J, Martin NJ (1996) Influence of environmental parameters on biomass production and nutrient removal in a high rate algal pond operated by continuous culture. Water Sci Technol 34:133-140

Deviller G, Aliaume C, Nava MAF, Casellas C, Blancheton JP (2004) High-rate algal pond treatment for water reuse in an integrated marine fish recirculation system: effect on water quality and sea bass growth. Aquaculture 235:331-344

Dubois M, Gillies KA, Hamilton JK, Rebers F, Smith PA (1956) Calorimetric method for determination of sugars and related substances. Anal Chem 28:350-356

Dumas A, Laliberte G, Lessard P, Noue J (1998) Biotretament of fish farm effluents using the cyanobacterium Phormidium bohneri. Aquacult Eng 17:57-68

Eker-Develi E, Kideys AE, Tugrull S (2006) Effect of nutrients on culture dynamics of marine phytoplankton. Aquat Sci 68:28-39

Garbisu C, Hall DO, Serra JL (1992) Nitrate and nitrite uptake by free-living and immobilized N-starved cells of Phormidium laminosum. J Appl Phycol 4:139-148

Garcia J, Green B, Oswald W (2006) Long term diurnal variations in contaminant removal in high rate ponds treating urban wastewater. Bioresour Technol 97:1709-1715

Gonzales LE, Canizares RO, Baena S (1997) Efficiency of ammonia and phosphorus removal from a Colombian agroindustrial wastewater by the microlagae Chlorealla vulgaris and Scenedesmus dimorphus. Bioresour Technol 60:259-262

Gonzalez-Bashan LE, Lebsky VK, Hernandez JP, Bustillos JJ, Bashan Y (2000) Changes in the metabolism of the microalga Chlorella vulgaris when coimmobilized in alginate with the nitrogen-fixing Phyllobacterium myrsinacearum. Can J Microbiol 46:653-659

Hu Q, Westerhoff P, Vermaas W (2000) Removal of nitrate from groundwater by cyanobacteria: quantitative assessment of factors influencing nitrate uptake. Appl Environ Microbiol 66(1):133139

Hyenstrand P, Burkert U, Pettersson A, Blomqvist P (2000) Competition between the green alga Scenedesmus and the cyanobacterium Synechococcus under different modes of inorganic nitrogen supply. Hydrobiologia 435:91-98

Janssen M, Bresser LD, Baijens T, Tramper J, Mur LR, Snel JFH, Wijffels RH (2000) Scale-up aspects of photobioreacters: effects of mixing-induced light/dark cycles. J Appl Phycol 12(3-5): 225-237

Jimenez-Perez MV, Sanches-Castillo P, Romera O, FernandezMoreno D, Perez-Martinez C (2004) Growth and nutrient removal in free and immobilized planktonic green algae isolated from pig manure. Enzyme Microbial Technol 34:392-398

Karthikeyan P, Jayasudha S, Sampathkumar P, Manimaran K, Santhoshkumar C, Ashokkumar S, Ashokprabu V (2010) Effect of industrial effluent on marine diatom. Chaetoceros simplex (Ostenfeld, 1901). J. Appl. Sci. Environ. Manage. 14(4):35-37

Karthikeyan P, Jayasudha S, Manimaran K, Sampathkumar P, Suriya S (2011) Effect of cadmium on marine diatom. Chaetoceros curvisetus with different ambient iron concentrations. Asian $\mathrm{J}$ of Biochem Pharm Res 2(1):240-248

Lafarga-De la Cruz F, Valenzuela-Espinoza E, Millan-Nunez R, Trees CC, Santamaria-del-Angel E, Nunez-Cebrero F (2006) Nutrient uptake, chlorophyll a and carbon fixation by Rhodomonas sp. (Cryptophyceae) cultured at different irradiance and nutrient concentrations. Aquacult Eng 35:51-60

Laliberte G, Lessard P, Noue J, Sylvestre S (1997) Effect of phosphorus addition on nutrient removal from wastewater with the cyanobacterium Phormidium bohneri. Bioresour Technol 59:227-233

Lee K, Lee CG (2001) Effect of light/dark cycles on wastewater treatments by microalgae. Biotechnol Bioprocess Eng 6:194-199 
Lowry OH, Rosebrough NH, Farr AL, Randall RL (1951) Protein measurement with the Folin phenol reagent. J Biol Chem 193: 265-275

Manimaran K, Karthikeyan P, Ashokkumar S, Ashok Prabu V, Sampathkumar P (2011) Effect of copper on growth and enzyme activity of marine diatom Odontella mobiliensis. Bull Environ Contam Toxicol 88(1):30-37

Martinez ME, Castillo JM, Yousfi EF (1999) Photoautotrophic consumption of phosphorus by Scenedesmus obliquus in a continuous culture. Influence of light intensity. Process Biochem 34:811-818

Martinez ME, Sanchez S, Jimenez JM, Yousfi FE, Munoz L (2000) Nitrogen and phosphorus removal from urban wastewater by the microalga Scenedesmus obliquus. 73(3):263-272

OECD (2002) Guidelines for the testing of chemicals, Lemna sp. Growth inhibition test draft guideline 221. Paris, France

Olguin EJ, Galicia S, Mercado G, Perez T (2003) Annual productivity of Spirulina (Arthrospira) and nutrient removal in a pig wastewater recycle process under tropical conditions. J Appl Phycol 15:249-255

Sciandra A, Lazzara L, Claustre H, Babin M (2000) Response of growth rate, pigment composition and optical properties of Cryptomonas sp. to light and nitrogen stress. Mar Ecol Prog Ser 201:107-120

Strickland JDH, Parsons TR (1972) A practical handbook of seawater analysis. Bull Fish Res Board Can 167:311
Tam NFY, Wong YS (2000) Effect of immobilized bead concentrations on wastewater nutrient removal. Environ Pollut 107:145151

Thakur A, Kumar HD (1999) Nitrate, ammonium, and phosphate uptake by the immobilized cells of Dunaliella salina. Bull Environ Contam Toxicol 62:70-78

Urrutia I, Serra JL, Llama MJ (1995) Nitrate removal from water by Scenedesmus obliquus immobilized in polymeric foams. Enzyme Microbial Technol 17:200-205

Valderrama LT, DelCampo CM, Rodriguez CM, De-Bashan LE, Bashan Y (2002) Treatment of recalcitrant wastewater from ethanol and citric acid production using the micro alga Chlorella vulgaris and macrophyte Lemna minuscula. Water Res 36: 4185-4192

Van der Steen P, Brenner A, Van Buuren J, Oron G (1999) Posttreatment of UASB reactor effluent in an integrated duckweed and stabilization pond system. Water Res 33:615-620

Xin L, Hong-ying H, Ke G, Ying-xue S (2010) Effects of different nitrogen and phosphorus concentrations on the growth, nutrient uptake, and lipid accumulation of a freshwater micro alga Scenedesmus sp. Bioresour Technol 101:5494-5500

Young E, Beardall J (2003) Rapid ammonium and nitrate-induced perturbations to chl ' $a$ ' fluorescence in nitrogen-stressed Dunaliella tertiolecta (Chlorophyta). J Phycol 39:332-342 